\title{
Depletion, metasomatism and water distribution in the oceanic lithospheric mantle
}

\author{
Michael Bizimis ${ }^{(e)}$, AARON W. AshLEY ${ }^{13}$, HugueS \\ BEUNON ${ }^{3}$, SIERRA PATTERSON ${ }^{1}$, LUC S. DOUCET ${ }^{4}$, \\ AnNe H. Peslier $s$, NAdine MATTIELI ${ }^{3}$ \\ SEOS, Univ. of South Carolina, Columbia SC, 29206 USA \\ (* correspondance: mbizimis@geol.sc.edu) \\ ${ }^{3}$ EOAS, Florida State Univ., Tallahassee FL, 32304 USA \\ ${ }^{3}$ G-Time, Univ. Libre de Bruxelles, 1050 Brussels, Belgium \\ ${ }^{4}$ EDRG, Curtin University, Perth, WA, 6845, Australia \\ Jacobs, NASA-JSC, XI03, Houston, TX 77058, USA
}

The concentration of hydrogen $\left(\mathrm{H}\right.$, reported as $\mathrm{H}_{2} \mathrm{O}$ ppm by weight) controls key physical properties of mantle peridotite (rheology, melting, electrical conductivity). As $\mathrm{H}$ is highly incompatible in bulk peridotite, melting will effectively dehydrate the residual lithospheric mantle. However, existing data on oceanic peridotites show variable and higher $\mathrm{H}_{2} \mathrm{O}$ concentrations than predicted for melt residues, implying a role for metasomatism in "rehydrating" the mantle lithosphere. Yet, the competing roles of depletion and metasomatism, and how metasomatism controls the $\mathrm{H}_{2} \mathrm{O}$ systematics of the lithospheric mantle remain unclear.

We present $\mathrm{H}_{2} \mathrm{O}$ (measured by FTIR), major and trace element concentrations on minerals from oceanic peridotite xenoliths from Hawaii, Samoa, Canaries and the Kerguelen archipelago. Orthopyroxene (opx, the dominant host of $\mathrm{H}_{2} \mathrm{O}$ in clinopyroxene (cpx)-poor peridotites) from Samoa and Kerguelen depleted peridotites have the lowest $\mathrm{H}_{2} \mathrm{O}$ contents, $\sim 10-70 \mathrm{ppm}$. The Hawaiian peridotite opx and cpx show two distinct trends of decreasing $\mathrm{H}_{2} \mathrm{O}$ with decreasing $\mathrm{Al}$ contents, a high $\mathrm{H}_{2} \mathrm{O}$ trend for Salt Lake Crater, Aliamanu, and a low $\mathrm{H}_{2} \mathrm{O}$ trend for Pali, Kauai. In the Kerguelen and Canaries peridotites cpx $\mathrm{H}_{2} \mathrm{O}$ contents increase with increasing intensity of carbonatite metasomatism (e.g., Ti depletions, $\mathrm{Ce} / \mathrm{Yb}$ ), but they have lower $\mathrm{H}_{2} \mathrm{O}$ concentrations than Hawaiian cpx affected by silicate metasomatism, approximated by the high $\mathrm{H}_{2} \mathrm{O}$ contents of pyroxenites.

While each sample location has distinct $\mathrm{H}_{2} \mathrm{O}$ vs. major element trends, these and literature data show decreasing $\mathrm{H}_{2} \mathrm{O}$ content in oceanic peridotites with increasing depletion. In turn, carbonatite and silicate metasomatism each result in distinct $\mathrm{H}_{2} \mathrm{O}$ vs. trace element systematics, but carbonatite is less effective in rehydrating the lithosphere than silicate metasomatism, likely due to the lower activity of $\mathrm{H}_{2} \mathrm{O}$ in $\mathrm{CO}_{2}$ bearing fluids. The role of diffusion in smoothening out $\mathrm{H}_{2} \mathrm{O}$ gradients in the lithosphere appears relevant only on the sampling scale of each location. 